\author{
Changing Societies \& Personalities, 2017 \\ Vol. 1, No. 4 \\ http://dx.doi.org/10.15826/csp.2017.1.4.020
}

\title{
EDITORIAL
}

\section{Do We Still Need to Defend the Right to Say What We Disapprove?}

\author{
Elena Stepanova \\ Institute for Philosophy and Law, Ural Branch, the Russian Academy of Sciences, \\ Yekaterinburg, Russia
}

The idea of the freedom of conscience as an outcome of the long history of religious conflicts in Europe emerged in XVII-XVIII centuries as protection of minority ('dissident') religious beliefs, which for various reasons stood outside the mainstream Christian confessions and established churches. Since then, it is widely acknowledged that the freedom of conscience as the preserve of individual belief both framed by and independent of theological standards is the core of the human rights and civil liberty.

For many centuries, Christianity was quite intolerant towards deviations of the mainstream dogmas; the deviations were considered heretical and severely punished. When Christianity became official religion of the Roman Empire, "religious freedom was replaced by religious oppression as enemies of the Church and enemies of the State became more of less interchangeable. Moreover, since many 'enemies of the State' were also Christian, this resulted in wars which pitted believers against believers". (Evans, 1997, p. 2) Similar developments arose in non-Christian societies outside Europe, albeit to a different degree: for example, in Muslim lands, the dominant religious forces imposed various limitations on minority religions, although in general, intolerance of other religions was not as extreme as in Europe. The common development in the medieval period of the European history was the unity of the state central authority and the dominant religion, which was aimed at the prevention of practicing of other religious beliefs. It was almost impossible to view conscience outside a theological framework: "The result was that while the minority approach towards religious belief might have differed from the majority, thereby raising an issue of conscience, a similar oppressive outcome resulted when, or if, the minority assumed power" (Hammer, 2018, p. 12).

The Reformation generally recognized the individual conscience, but only in the framework of the word of God. Nevertheless, the idea of the personal

(C) 2017 Elena Stepanova 
understanding of Scriptures inevitably led to the freedom of thought outside Christian dogmatic. The next stage of the freedom of conscience was the recognition of the religious freedom in post-Westphalian Europe. The diversification of Christianity during the Reformation and the rise of the secular states resulted in the acceptance of personal liberty and individual freedom of belief including atheism and agnosticism. Two writers-Pierre Bayle in France and John Locke in England-developed ideas of the independent approaches to ethics based on conscience as the internal source of ethical knowledge, and religious toleration based on the recognition of the inherent limitations of the human's ability to comprehend the nature of a deity.

Gradually, human beings acquired the privilege of a reasonable inquiry into nature, society and human subjectivity. It was a sense, in Charles Taylor's words, that "freedom of conscience was a value that should be espoused, independent of confessional adherence, that there was something retrograde in its violation, something uncivilized". (Taylor, 2007, p. 259) In political practice, it resulted in the separation of church and state, which was for the first time articulated in the US Constitution, thus legitimizing the very term "conscience" as opposed to "religion". So, the right to freedom of conscience emerged through centuries as an independent right that need not centre on religious beliefs (Hammer, 2018, p. 26), thereby comprising the right to freedom of thought and religion.

In the $X X^{\text {th }}$ century, freedom of conscience was codified in the international human rights system as the forming part of the corpus of human rights, because it is assumed that without freedom of conscience there could be no real freedom of speech, opinion, expression, peaceful assembly, association or participation in social life. The creation of the League of Nations following the World War I generally indicated that religious tolerance was recognized as a fundamental concept to ensure peaceful coexistence among countries in the world. Although the League's Covenant did not contain special article on the freedom of conscience, later the principle was fully implemented in the "Universal Declaration of Human Rights", which was proclaimed by the United Nations General Assembly in Paris on 10 December 1948 as a common standard of achievements for all peoples and all nations. The Article 18 of the UDHR states: "Everyone has the right to freedom of thought, conscience and religion; this right includes freedom to change his religion or belief, and freedom, either alone or in community with others and in public or private, to manifest his religion or belief in teaching, practice, worship and observance."

Today, in most parts of the world freedom of conscience, thought and religion is taken for granted, and many people look at is as a natural human right. Nevertheless, we do not have to forget that this right has been acquired in quite recent times, and the way to it was dramatic (Bury, 1913). Even in nowadays, article 18 is violated constantly, and millions of people around the world continue to be oppressed because of their beliefs.

At the same time, the UDHR in general, and Article 18 in particular remains the subject of serious debates. It is generally agreed that the UDHR was adopted in the aftermath of the World War II as an attempt to ensure that such a catastrophe would never take place again. Nevertheless, eventually the universality of the 
Declaration has been questioned due to the undermining of contextualization, or acknowledging cultural differences that exist between societies in different parts of the world. Religious beliefs and moral standards are shaped by the particular socialcultural context, and the very concept of the freedom of conscience and freedom of religion emerged in Western European Christian context; it means that its content and significance could not be the same everywhere and for everyone.

Contemporary 'post-secular' societies are characterized by religious diversity and deprivatization of religion. They embrace freedom of conscience and allow each individual to decide for himself/herself how to pursue the ultimate meaning of life. They are marked by the fact that religious beliefs - both historical and new ones - as well as atheism, agnosticism and non-religious lifestyles, are equally viable options. Nevertheless, post-secularism (whatever it means) challenges two main principles of secularism-equal respect to all beliefs, and freedom of conscience-and its two operative modes-separation of religious institutions and state, and state neutrality towards religions. Consequently, the popular expression, which is prescribed to Voltaire: the willingness to defend to the death the one's right to say what is disapproved-remains a disputable subject.

The current issue of Changing Societies \& Personalities discusses some aspects of the freedom of consciences and freedom of religion in past and present.

Ivan Strenski's On an Antinomy in the Discourses of Freedom of Religion and Freedom of Conscience introduces the new section of the journal-ESSAY-and opens discussion on the questions: Can freedom of religion and religious freedom really be separated in reality? Does not the one actually require or entail the other? In reflecting on the distinctiveness of the terms "freedom of conscience", "freedom of religion", and "religious freedom", as well as their interconnection, Strenski goes back into the genealogies of the notions and argues that freedom of conscience and freedom of religion not necessarily imply each other. He uses some decisions of the US Supreme Court, as well as historical examples, as illustrations of the controversy of individual and institutional religious freedom.

Tatyana Nikolskaya in the paper Human Rights Advocacy of Baptist Initiators stresses that knowing the history of Protestants in the USSR is especially important due to resent cases of violations of the religious freedom and non-traditional denominations' rights in Russia, as well as the necessity not to forget about tragic pages of persecution and discrimination in the past. The paper elucidates the unknown pages of Evangelical Christians and Baptists' struggle for the right of believers, which according to the author formed the only mass human rights movement in the USSR. Although Evangelical Christians and Baptists traditionally were not interested in political and civil activity, in $1960^{\text {th }}$ many of them started to participate in the struggle for the independence from the state and the right to freely profess their faith being influenced by the assurance in weakening of totalitarian power in the Khrushchev's "thaw". This did not came true, and hundreds of people were convicted of religious activities and sentenced to prison. Nikolskaya devotes special section of her paper to the participation of women-believers in human rights activities, and underlines: "It remains a mystery how these women, mostly 
burdened by families, managed to travel so actively around the country, to study a lot of complicated cases, to write and send letters of intercession..." Finally, she stresses the mixed consequences of the human rights activities of Baptist Initiators, and mentions criticism of the Initiators' protection of the rights of believers from within their own Baptist community because of a fear to complicate their situation, and of persistent unwillingness to engage in politics.

Mark S. Cladis's paper Solidarity, Religion, and the Environment: Challenges and Promises in the $21^{\text {st }}$ Century argues that religion and solidarity should not be treated as anomalies in modernity because solidarity plays an important role in establishing freedom of conscience and individual rights. In addition, religion and solidarity could be seen as cultural resources in dealing with the environmental problems. He stresses that "both religion and solidarity can act as double-edged swords" in a sense that they could contribute to peace and justice, as well as reinforce oppressive social practices. In exploring religion and solidarity, Cladis refers to E. Durkheim who had discovered religion as social ideas, beliefs and practices that shapes a society's moral universe, and solidarité as an enduring source of human social identity and fellowship. Mentioning the today's suspicion about the concept of solidarity due to doubt in common ground among diverse human communities and individuals, Cladis insists that solidarity remains a powerful notion, which celebrate diversity as a precious public resource.

Gnana Patrick in the paper Religion and the Subaltern Self: An Exploration from the Indian Context introduces the concept of the Subaltern Studies Project (SSP) and the interface between religion and the subaltern self in the Indian context. The term "subaltern" was taken from Italian Marxist Antonio Gramsci who meant by it the subjected underclass under the dominant power influence. The term underlines the recognition of the historically subordinate position of various groups because of race, class, religion, ethnicity, gender, sexual orientation, etc., and seeks to provide them a voice and agency. The author clarifies the relationship between the subaltern studies and the post-colonial studies in their approach towards religion and stresses the difference between them. The basic argument of the paper is that religion, considered on its own, could be an emancipatory experience for the subaltern self, due to its effective interpretive potential for the subaltern self to take on the caste system, which remains deeply entrenched into the Indian collective consciousness. Examples from the pre-modern and modern periods of the history of India are observed in order to support the argument.

In the BOOK REVIEW section, Anatoliy Denysenko reviews the Roman Soloviy's volume Fenomen poiavliaiushcheisia tserkvi v kontekste teologicheskikh i ekklesiologicheskikh transformatsii v sovremennom zapadnom protestantizme [The phenomenon of the emerging church in the context of the theological transformations of the ecclesiastical transformations in contemporary Western Protestantism, 2017]. He considers the book as one of the most important not only in the Ukrainian (post-) Protestant theological environment, but also in the ecclesiastical sphere of the evangelical communities of the post-Soviet space. In reflecting on the nature of (post-) Protestantism and the phenomenon of the "Emerging Church", Denysenko 
following Soloviy in the search of a new Christian theology, which could find new ways of expressing the Gospel in the contemporary culture.

The discussions on the freedom of conscience, freedom of religion and religion freedom in the past and present will be continued in the subsequent issues of our journal.

We welcome suggestions for thematic issues, debate sections and other formats from readers and prospective authors and invite you to send us your reflections and ideas!

For more information, please visit the journal web site: https://changing-sp.com/

\section{References}

Bury, J. B. (1913). A History of Freedom of Thought. New York, NY: Henry Holt and Co.

Evans, M. D. (1997). Religious Liberty and International Law in Europe. Cambridge, UK: Cambridge University Press.

Hammer, L. M. (2018). The International Human Right to Freedom of Conscience: Some Suggestions for Its Development and Application. London: Routledge.

Taylor, Ch. (2007). A Secular Age. Cambridge, MA: Harvard University Press. 